\title{
KAJIAN AGRONOMI DAN PEMANFAATAN BUAH GANDARIA (Bouea macrophylla.Griff)
}

\author{
Vilma L. Tanasale \\ Staf Pengajar Faperta - UNPATTI Ambon, e-mail: -
}

\begin{abstract}
ABSTRAK
Tanaman Gandaria (Bouea macrophylla) merupakan tanaman buah tropik yang penyebarannya sangat jarang dijumpai di Indonesia. Penyebaran tanaman gandaria di daerah Maluku hanya dijumpai pada beberapa daerah yaitu pulau Ambon sebagai sentra produksi terbesar dan selebihnya di Kabupaten Maluku Tengah terutama pulau Saparua dan Seram Barat Kurangnya informasi dan data tentang buah gandaria masih menjadi kendala sehingga perlu membuat tulisan tentang buah gandaria terutama dari aspek agronomi dan pemanfaatannya didalam masyarakat saat ini. Diharapkan tulisan ini dapat memberikan informasi kepada masyarakat dalam pelaksanaan budidaya tanaman gandaria sekaligus dapat digunakan sebagai landasan informasi penelitian lebih lanjut tentang tanaman ini.
\end{abstract}

\section{Kata Kunci: Botanical aspects, ecological aspects, cultivating techniques}

\section{PENDAHULUAN}

Gandaria adalah tanaman buah di Maluku yang berpotensi sampai saat ini belum banyak dilihat sebagai objek studi penelitian ilmiah karena kelangkaannya di Nusantara ini. Tanaman gandaria merupakan tanaman buah tropik yang penyebarannya sangat jarang dijumpai di Indonesia. Penyebaran tanaman gandaria di daerah Maluku hanya dijumpai pada beberapa daerah yaitu pulau Ambon sebagai sentra produksi terbesar dan selebihnya di Kabupaten Maluku Tengah terutama pulau Saparua dan Seram Barat .

Pulau Ambon secara geografis terletak pada posisi $3-4^{\circ}$ Lintang Selatan dan $128-129^{\circ}$ Bujur Timur, dengan luas wilayah pulau Ambon seluruhnya $337 \mathrm{~km}^{2}$ disusun oleh dua jazirah yaitu Jazirah Leihitu dan Jazirah Leitimur. Pulau ini ditumbuhi oleh jenis-jenis lokal gandaria yang kehadirannya melimpah dan membentuk hutan yang dijadikan hutan lindung. Gandaria merupakan salah satu pohon yang mendominasi di hutan daerah tangkapan air, sangat bermanfaat untuk menyimpan air dan melindungi daerah sekitar tangkapan air dari bahaya banjir dan erosi (Papilaya 2002). Di pulau Ambon tumbuhan ini tumbuh bersama tumbuhan lain seperti manggis, durian, salak, lansat, kecapi, dan juga tumbuhan pengganggu lainnya dengan kepadatan dan frekuensi kehadiran serta kemampuan menyebar yang tinggi antara garis pantai sampai daerah pegunungan. Keadaan ini bila dibiarkan, pertumbuhan dan perkembangannya tanaman gandaria akan semakin terdesak. Tanaman pohon ini lebih banyak dijumpai di dataran sepanjang daerah aliran sungai sampai pada lereng di sekitar aliran sungai.

Daerah-daerah di pulau Ambon yang terdapat di daerah perbukitan yang sesuai berdasarkan syarat tumbuh tanaman gandaria, yaitu Dusun Kusu-Kusu Sereh Desa Urimessing Kecamatan Nusaniwe dan Desa Soya Kecamatan Sirimau yang merupakan daerah pertanaman buah yang sangat potensial.

Kurangnya informasi dan data tentang buah gandaria masih menjadi kendala sehingga perlu membuat tulisan tentang buah gandaria terutama dari aspek agronomi dan pemanfaatannya didalam masyarakat saat ini. Diharapkan tulisan ini dapat memberikan informasi kepada masyarakat dalam pelaksanaan budidaya tanaman gandaria sekaligus dapat digunakan sebagai landasan informasi penelitian lebih lanjut tentang tanaman ini.

\section{ASPEK BOTANI}

\subsection{Taksonomi}

Gandaria (Bouea macrophylla Griff.) termasuk divisi Spermatophyta, kelas dicotyledonae dalam suku Anacardiaceae. 
Beberapa jenis lainnya adalah jambu mete, mangga, bacang dan lain-lain. Gandaria mempunyai nama-nama daerah: remicu (Gayo), gandoriah (Mink), Borania (Day) ,jateke, gandaria, (Sd), gondariya (Jav), wates (Minatu), borania (Day.) kalawasa, rapo-rapo (Mak), gundangan (Melayu). (Heyne. 1987)

\subsection{Batang}

Gandaria berbentuk pohon yang tingginya mencapai $27 \mathrm{~m}$ dengan kulit kayu yang retakretak, berwarna coklat muda, dan seringkali memiliki ranting yang menggantung, tak berbulu, bersegi empat atau pipih.

\subsection{Daun}

Daunnya tunggal, berbentuk bulat telur lonjong sampai bentuk lanset atau bentuk pasak, ujungnya lancip (acute) sampai runcing (acuminate). Panjang Tangkai daun 1-2,5 cm.

\subsection{Bunga}

Bunga tersusun pada malai, muncul di ketiak daun, panjangnya $4-12 \mathrm{~cm}$, bagian-bagian bunganya sebagaian besar berkelipatan empat, berukuran kecil, cuping kelopak mahkotanya lonjong berukuran $(1,5-2,5) \mathrm{mm} \times 1 \mathrm{~mm}$, berwarna kekuning-kuningan, kemudian cepat berubah menjadi coklat.

\subsection{Buah}

Buah bertipe buah batu berbentuk agak bulat, daging buahnya kuning atau orange (Tjitrosoepomo, 1989 ; Van Steenis, 1992). Buahnya berbentuk bulat lonjong dan berukuran kecil (berdiameter $\pm 3-5 \mathrm{~cm}$ ), buah yang masak berwarna kuning kemerahan atau orange dan berair. Daging buahnya tebal, rasanya ada yang manis dan ada yang masam. Di sekeliling biji malahan sangat masam walaupun buahnya sudah masak benar (Heyne, 1987). Buah gandaria mempunyai biji yang cukup besar dan berkulit keras. Biji-biji yang besar, mempunyai persediaan makanan yang lebih banyak dan banyak membutuhkan air dalam pertumbuhannya.

\section{ASPEK EKOLOGI}

\subsection{Penyebaran Tanaman Gandaria}

Penyebaran suatu jenis tanaman pada lahan tertentu sangat dipengaruhi oleh 3 faktor yaitu iklim, fisiografi, dan biotik (Ewusie, 1980). Salah satu faktor lingkungan yang turut menentukan penyebaran tersebut adalah letak garis lintang dan tinggi suatu tempat, perbedaan iklim yang ditimbulkan oleh perbedaan ketinggian yang mempengaruhi proses fisiologi tanaman.

Tanaman gandaria merupakan tanaman tropik yang berasal dari Asia Tenggara, namun sekarang sudah tersebar sampai ke benua Amerika yang beriklim tropik. Penyebarannya ke daerah lain di Indonesia masih sangat jarang (langka). Salah satu pusat penyebarannya di Maluku yaitu Ambon dan Pulau Seram sedangkan Ambon terutama pada daerah-daerah pesisir antara lain (Poka - Rumah Tiga, Hunuth Durian patah, Hative Besar, juga terdapat pada daerah-daerah berombak dan berbukit seperti Desa Soya, Desa Urimessing, Suli, Waai dan Telaga Kodok. Selain itu juga terdapat di daerah Pulau Saparua dan Seram Barat, Kabupaten Maluku Tengah.

\subsection{Habitat}

Gandaria (B. macrophylla) merupakan tanaman tropik basah dan dapat tumbuh pada tanah yang ringan dan subur. Dapat tumbuh liar di hutan dataran rendah di ketingggiaan $500 \mathrm{~m}$ (Heyne 1087). Gandaria merupakan tanaman daerah tropik yang tumbuh baik pada ketinggian $5-800 \mathrm{~m}$ dpl namun sangat baik dan produktif sampai pada ketinggian $500 \mathrm{~m}$ dpl. Tanaman gandaria memiliki adaptasi yang cukup tinggi terhadap iklim dan tanah, namun untuk dapat tumbuh dengan baik dan berproduksi tinggi dibutuhkan kondisi iklim dan tanah tertentu.

\subsection{Iklim}

Suhu yang diinginkan sesuai dengan fluktuasi suhu harian rata-rata $24-28^{\circ} \mathrm{C}$, dengan curah hujan yang diinginkan berkisar antara 2500-3000 mm/tahun, bulan kering 3-4 bulan, kelembaban nisbi $70-80 \%$. . Distribusi curah hujan merupakan faktor untuk pertumbuhan dan produksi tanaman gandaria. Hal tersebut berkaitan dengan pembentukan tunas muda dan produksi. Pengaruh temperatur sangat berkaitan dengan ketersedian air, cahaya dan kelembaban.

Menurut Terra dalam Danoesastro (1970) untuk menunjukkan daerah penyebaran berbagai pohon-pohon dapatlah dipergunakan iklim menurut Mohr (1931) :

$A_{1}: 12$ bulan basah dan 0 bulan kering,

$\mathrm{A}_{2} \quad:<12$ bulan basah dan 0 bulan kering

$\mathrm{B}_{1}$ : < 12 bulan basah dan 1 bulan kering sampai 9 - 10 basah dan 2 kering

$\mathrm{B}_{2}$ : $<9$ bulan basah dan 2 bulan kering sampai $7-8$ basah dan 4 kering 
$\mathrm{C}$

: < 7 bulan basah dan 4 bulan kering sampai $5-6$ basah dan 6 kering

D : < 5 bulan basah dan 6 bulan kering sampai $2-4$ basah dan 8 kering

Sedangkan menurut tinggi permukaan air tanah dapat dibedakan :

a. sangat tinggi di atas $50 \mathrm{~cm}$

b. antara $50-150 \mathrm{~cm}$

c. di bawah $150-200 \mathrm{~cm}$

d. air tanah yang tidak dapat tercapai oleh akar.

Untuk tanaman gandaria sangat cocok dan sesuai untuk diusahakan pada daerah Acd sampai Bbc menurut kalsifikasi Mohr (1931).

Setiap organisme (tumbuhan) dipengaruhi oleh lingkungan tempat hidupnya. Barbour (1966) menyebutkan bahwa lingkungan adalah keseluruhan faktor biotik dan abiotik yang mengelilingi dan secara potensial mempengaruhi organisme dan lingkungan tersebut merupakan habitat organisme. Polunin (1996) menyebutkan bahwa tumbuhan hanya dapat hidup di tempat yang kondisinya sesuai. Oleh karena itu tumbuhan akan tumbuh dengan baik apabila keadaan lingkungan yang dibutuhkannya berada dalam rentang kebutuhan toleransi. Organisme (tumbuhan) akan melakukan tanggapan secara fisik maupun kimiawi sebagai usaha untuk melawan tekanan faktor lingkungan dan tetap hidup pada kondisi yang tidak menguntungkan sebagai suatu organism yang resisten (Levit, 1972). Pada organisme tertentu termasuk tumbuhan, mempunyai kemampuan beradaptasi dengan mempengaruhi lingkungan fisiknya untuk mengurangi faktor pembatas karena tumbuhan mempunyai sifat menetap dan tidak dapat menghindari tekanan faktor lingkungan yang ada (Odum, 1998).

Menurut Kimmins (1997) hubungan antara ketinggian tempat dan suhu adalah linier negatif. Adanya perubahan suhu lingkungan sangat mempengaruhi pertumbuhan dan metabolisme tanaman (Fitter dan Hay, 1994). Variasi suhu tanah sangat berpengaruh terhadap aktivitas perakaran dalam melaksanakan fungsinya untuk menyerap air maupun unsur hara (Arifin, 2003). Faktor kelembaban juga mempengaruhi evapotraspirasi dan jumlah air, serta berhubungan dengan suhu, curah hujan dan angin yang merupakan lingkungan tumbuh yang sangat menentukan kehidupan tumbuhan (Tjasyono, 2004).

Perbedaan ketinggian tempat dari permukaan laut juga mengakibatkan perbedaan intensitas cahaya yang diterima oleh tumbuhan. Pengaruh intensitas cahaya matahari terkait dengan sifat morfogenesis tumbuhan, fotosintesis, perkecambahan dan kecepatan pertumbuhan tanaman (Ariffin, 1979). Hasil suatu jenis tanaman bergantung juga pada interaksi antara faktor genetik dan faktor lingkungan seperti jenis tanah, topografi, dan pola iklim. Tanaman akan berdaya hasil tinggi jika mendapat air yang cukup pada waktu yang tepat, radiasi matahari yang tinggi dengan penyinaran yang cukup lama dan suhu yang sesuai (Tjasyono, 2004).

Faktor tinggi tempat permukaan bumi mempunyai kaitan dengan penerimaan matahari, suhu dan tekanan udara. Ketinggian tempat yang dikelompokan atas dataran tinggi, medium dan dataran rendah. Posisi wilayah-wilayah tersebut berpengaruh terhadap unsur-unsur musim atau iklim misalnya suhu udara, tekanan udara, kelembapan, hujan dan lain-lain (Arifin, 2003).

Levit (1972) menjelaskan bahwa, perubahan faktor lingkungan dapat terjadi secara vertikal, perubahan ketinggian pada umumnya disertai dengan keterbukaan, penurunan suhu dan tekanan udara. Penurunan suhu akan berpengaruh terhadap kadar uap air di udara (kelembaban), sedangkan perubahan tekanan udara akan mengakibatkan pergerakan masa udara.

Greig \& Smith (1983) menjelaskan perubahan suhu dan tekanan udara mengakibatkan terjadinya pergerakan masa udara dari tempat yang tekanan udaranya lebih tinggi ke tempat yang tekanan udaranya lebih rendah. Arah pergerakan massa udara akan berpengaruh pada uap air yang dibawanya, dengan demikan akan mencurahkan hujan di suatu tempat. Akibatnya tempat-tempat tertentu dipermukaan bumi akan memiliki iklim yang khas. Tempat yang dipengaruhi oleh pengairan (danau, laut) akan berbeda dengan tempat yang dipengaruhi oleh tebing dan lembah. Pada akhirnya iklim setempat dengan faktor edafiknya (tanah) akan mempengaruhi keadaan organisme (tumbuhan) yang berada di tempat tersebut.

Faktor iklim dan tanah mempunyai pengaruh yang sangat besar bagi pertumbuhan tanaman antara lain keadaan hujan, kedaan air tanah, dan letak tinggi daerah tanaman dari permukaan laut. Ada jenis tanaman tumbuh baik pada ketinggiaan sampai $500 \mathrm{~m}$, ada juga yang tumbuh baik pada ketinggian $1000 \mathrm{~m}$ dan ada yang tumbuh baik pada dataran rendah. Gandaria merupakan jenis pohon buah-buahan yang dapat tumbuh pada bulan basah $9-11$ bulan dan $1-3$ bulan kering.(AKK,1975). 
Iklim sangat banyak diubah oleh ketinggian tempat. Bagian-bagian yang lebih tinggi dari suatu daerah umunya lebih banyak di jumpai batu-batuan dan lebih banyak kena matahari, sedangkan pada bagian-bagian yang lebih rendah lebih banyak dijumpai pasir. Pada elevasi yang lebih tinggi radiasi matahari selama cuaca terang lebih terik dari elevasi-elevasi yang rendah. Lembah-lembah yang curam lebih banyak terdapat angin dibandingkan dengan lereng-lereng didekatnya yang terletak beberapa ratus meter lebih tinggi (Soekartjo 1996).

\subsection{Tanah}

Pada umumnya tanaman gandaria dapat tumbuh pada berbagai jenis tanah baik daerah datar, berombak, berbukit sampai bergunung. Tipe tanah yang dikehendaki adalah berpasir dengan tingkat kesuburan tanah yang baik sampai sedang dan $\mathrm{pH}$ 4,5-7,0 (Zaibin, 1998 dalam Sukarman, 2002). Persyaratan fisik lainnya yang cocok untuk pertumbuhan dan produksinya adalah tanah gembur, ringan, drainase, dan aerasi baik. Faktor fisik tanah erat kaitannya dengan daya penentrasi dan kemampuan akar menyerap hara. Jenis-jenis tanah yang dapat dijumpai pada habitat tanaman gandaria khususnya di pulau Ambon antara lain regosol, kambisol, alluvial, litosol, dan burnizem.

\section{PERBANYAKAN TANAMAN}

Secara ekologi menurut Tirtawinata, (2002) bahwa gandaria dapat menjadi tolok ukur dalam budidaya tanaman. Berbagai permasalahan yang dihadapi dalam budidaya gandaria seperti pertumbuhannya sangat lambat, untuk berbuah butuh waktu 12-15 tahun walupun telah dilakukan pemupukan dan pemangkasan. Belum pernah berhasil membudidayakan gandaria dalam pot. Ketika anakannya dipindahkan, perakaran lemah sehingga tanaman stress dan layu. Perbanyakan dengan cangkok sering berakibat akar gagal tumbuh. Dengan cara okulasi, perlu waktu yang lama karena batang bawah baru siap diokulasi dalam 3-4 tahun. Belum lagi mata tunas muda kering karena kulit tipis. Upaya yang sementara dilakukan adalah penanaman bibit dengan cara semai biji, tetapi sekarangpun belum membuahkan hasil. Selain itu upaya merangsang tanaman gandaria membentuk bunga dan buah belum berhasil (Tirtawinata, 1993).

\section{HASIL PANEN DAN KUALITAS BUAH GANDARIA}

\subsection{Hasil Panen}

Di Ambon buah gandaria merupakan salah satu jenis buah yang cukup diminati, memberi indikasi akan prospeknya dalam meningkatkan pendapatan masyarakat yang cukup baik. Produksi dan perdagangan buah ini cukup mahal. Harga buah gandaria kadang-kadang sama dengan harga buah mangga yang terbaik, terutama pada saat di luar musim. Pohon gandaria dewasa dapat menghasilkan 200-500 $\mathrm{kg}$ buah dalam satu musim. Berdasarkan hasil wawancara dengan masyarakat, gandaria biasanya dipanen sekali dalam 4-5 bulan dari bulan Maret sampai Juli.

Pada dasarnya gandaria merupakan salah satu tanaman hortikultura yang apabila diperhatikan secara serius oleh pemerintah mempunyai potensi yang besar untuk meningkatkan kebutuhan buah. Biasanya panen pertama untuk tanaman yang berasal dari semai adalah 10-15 tahun setelah tanam, atau kalau berasal dari perbanyakan vegetatif hanya 5-6 tahun. Hasil panen buah gandaria akan terus meningkat dengan bertambahnya umur tanaman (Riffai 1997 cit. Papilaya 2007).

Di beberapa sentra gandaria di pulau Ambon masih merupakan tanaman kebun masyarakat, secara komersial masih terbatas pemasarannya. Di samping itu tanaman gandaria umunya masih merupakan tanaman kebun masyarakat yang tumbuh dari asal biji dan relasi pasar kurang sehingga masyarakat belum mendapat keuntungan yang besar. Sampai saat inipun belum ada sentuhan teknologi pengolahan produksi buah gandaria. Padahal sebenarnya gandaria sudah merupakan salah satu tanaman buah yang potensial untuk dikembangkan di pulau Ambon.

\subsection{Kandungan Buah Gandaria}

Kandungan komposisi buah gandaria setiap $100 \mathrm{~g}$ bagian yang dapat dimakan adalah $85 \mathrm{~g}$ air, $12 \mathrm{mg}$ protein, $600 \mathrm{mg}$ serat, $230 \mathrm{mg}$ abu, $6 \mathrm{mg}$ kalsium, 10,8 $\mathrm{mg}$ fosfor, $0,31 \mathrm{mg}$ besi, 0,043 mg karotena, 0,031 mg tiamina, 0,025 mg riboflavin, 0,286 mg niasina, dan $75 \mathrm{mg}$ vitamin. Kandungan vitamin A dan C dari gandaria menduduki urutan kedua setelah mangga dan jambu mete.

Komponen daging buah gandaria terdiri dari sejumlah unsur yang merupakan sumber vitamin dan mineral yang berguna untuk tubuh. Protein yang terkandung dalam buah biasanya 
dalam bentuk enzim yang berguna membangun sel atau mengganti sel-sel tubuh yang mati. Enzim dalam buah menyebabkan perubahan kimia dan metabolisme. Enzim sering berefek kurang baik pada warna daging selama disimpan, warna alaminya akan berubah menjadi coklat atau hitam sering juga disebabkan tannin (AAK, 1975). Kondisi seperti ini juga sering dijumpai pada buah gandaria yang disimpan dalam waktu yang lama.

Daging buah gandaria mempunyai rasa manis diduga mengandung karbohidrat terdiri dari gula sederhana, tepung, glukosa, fruktosa dan sukrosa. Gula tersebut memberikan rasa manis dan tenaga yang dapat digunakan oleh tubuh. Zat lain seperti selulosa dan pektin yang berguna untuk tubuh, terutama memudahkan pencernaan rasa kelat (sepet) pada buah gandaria kemungkinan disebabkan oleh tannin. Rasa karakteristik buah gandaria kemungkinan ada hubungannya dengan campuran gula, asam dari vitamin $\mathrm{C}$ dan tannin yang terdapat dalam daging buah yang bermanfaat untuk daya tahan tubuh (Wirakusumah, 1995 cit. Papilaya 2007).

\subsection{Pemanfaatan Buah Gandaria}

Gandaria bermanfaat sebagai pohon buahan yang popular, buahnya mirip buah mangga kecil. Walaupun rasanya agak masam, bahkan yang matang sekalipun, buah gandaria biasanya dikomsumsi dalam keadaan segar, atau diolah menjadi sirup atau dijadikan manisan yang lezat sekali. Tetapi, pemanfaatan buah mudanya lebih penting, yaitu merupakan bahan penyedap pada sambal gandaria yang khas, dan dalam asinan, serta keping bijinya yang berukuran besar dan berwarna lembayung cerah dapat meningkatkan daya tarik masakan. Seringkali daun mudanya yang berwarna ungu tua (warna putih sekali sewaktu mulai muncul) juga dikomsumsi segar, dimakan dengan sambal gandaria.

\section{KENDALA BUDIDAYA DAN PENGEMBANGAN \\ Dalam mengembangkan tanaman Buah} Gandaria (Bouea macrophylla. Griff) didaerah Maluku masih terdapat beberapa kendala antara lain :

a). Data yang akurat tentang luasan lahan dan data produksi tanaman buah gandaria per areal pertanaman gandaria di Maluku belum lengkap.

b).Penurunan produksi buah gandaria, karena kurangnya pemahaman tentang cara budidaya yang baik dan cara pengendalian gulma yang tepat, sehingga hanya mengandalkan produksi tanaman yang tumbuh liar dihutan tampa tindakan pemeliharaan tanaman yang tepat.

c). Alih fungsi lahan hutan untuk berbagai tujuan pembangunan berdampak pada penurunan populasi gandaria.

\section{PENUTUP}

\subsection{Kesimpulan}

1. Tanaman buah gandaria memiliki berbagai manfaat antara lain sebagai buah segar, sirup, manisan dan asinan

2. Pengembangan tanaman buah gandaria selain mendukung upaya pemeliharaan sumber plasmanutfah di alam, juga memiliki nilai ekonomi yang tinggi sehingga penerapan teknik budidaya tanaman buah merah yang tepat peningkatan produksi tanaman dapat dicapai.

\subsection{Saran}

Perlu adanya peningkatan produksi tanaman gandaria dengan cara :

a). Melakukan survey untak mendapatkan data yang akurat tentang luasan lahan dan produksi buah gandaria per satuan luas.

b). Perlu dilakukan penyuluhan tentang teknik budiaya yang tepat agar dapat meningkatkan produksi tanaman buah gandaria sehingga pemanfaatan yang berkelanjutan dapat diwujudkan.

c). Perlu adanya informasi kepada petani tentang cara pengolahan pasca panen buah gandaria yang tepat.

\section{DAFTAR PUSTAKA}

AAK. 1975. Bertanam Pohon Buah-Buahan. Yogyakarta, Kanisius.

Barbour. G. M., JK Burk and W.D. Pitts, 1987. Terresterial Plat Ekology. The Benyamin Cummings Publishing Company, Inc. California..

Eussen. J.H.H., S. Slamet, and D. Soeroto., 1976. Competition between Imperata cylindrical (L). Beauv. and Some Crop Plantas. Bogor. Biotrop Bull. No 10. 
Fitter. A. H dan R. K. M. Hay. 1994 (Fisiologi Lingkungan Tanaman, Diterjemahkan ahli bahasa Sri Andani dan ED. Purbayanti) Gajah Mada Press, Yogyakarta.

Greigh and Smith. P. 1983. Quantitatif Plant Ecology $.3^{\text {rd }}$ Ed. University of California: Press Bekerley. Heyne. 1987. Tumbuhan Berguna Indonesia. Badan Litbang Departemen Kehutanan,,Jakarta.

Irwanto. 2007. Analisis Vegetasi Untuk Penegelolaan Kawasan Hutan Lindung pulau Marsegu, kabupaten Seram Bgaian Barat, provinsi Maluku, Tesis. Program studi Ilmu Kehutanan UGM, Yogyakarta.

Levit. J. 1972. Respons of Plants to Enviromental Stress. Academic Press, New York.

Moenandir. J 1985. Pengantar Ilmu Gulma dan Pengendalian Gulma. Ilma Gulma I Rajawali Press, Jakarta

Moenandir. J. 1993. Ilmu Gulma dalam Sistem Pertanian. Rajawali Grafindo Persada, Jakarta.

Najiyati. S. dengan Danarti, 2003. Budidaya dan Penanganan Pascapanen. Edisi revisi. Kanisius, Yogyakarta.

Nasution. U. 1984. Gulma dan Pengendaliannya di Perkebunan Karet Sumatra Utara dan Aceh, Tanjung Morawa: Pusat Penelitian \& Pengembangan Perkebunan.

Odum. E.P. 1971. Fundamentals of Ecology. Third Edition Philadelphia; W. B. Sasunsers.

Papilaya, P. M. 2002. Keanekaragaman. Pola Penyebaran dan Asosiasi Jenis Pohon di Hutan Daerah Tangkapan Air dusun Kusu-Kusu Sereh kota Ambon. Tesis , UNM, Malang.

Papilaya. P.M. 2007. Kajian Ekologi Gandaria (Bouea macrophylla) Hubungannya Dengan Produksi Dan Kualitas Buah Pada Ketinggian Dari Permukaan Laut Yang Berbeda Di Pulau Ambon. Disertasi, UNM, Malang.

Polunin. N. 1994. Pengantar Geografi Tumbuhan dan Beberapa Ilmu Serumpun. Alih Bahasa Tjitrosoepomo,. Gadjah Mada Univerrsity Press, Yogyakarta.

Rifai. M. A. 2005. Sumber Nabati Asia Tenggara. Buah-buahan yang Dapat Dimakan. Jurnal. Jakarta. PT Gramedia Pustaka Utama. Http//wwww.unhasaluminet/direktri php3. (diakses, 15 April 2005)

Sastroutomo.S.S. 1988. Ekologi Gulma, PT. Gramedia Pustaka Utama. Jakarta.

Sukarman. 2002. Pengolahan dan Penanganan Benih Aneka Tanaman Perkebunan. Jurnal Perspektif. $1(2): 41-54$.

Tirtawinata. M. R. 1993. Mengatur Tanaman Berbuah. Trubus XXIV (284).

Tjasyono. B. 2004. Klimatologi. TB, Bandung.

Tjitrosoedirdjo. S.,Utomo, I.H. dan J. Wiroatmodjo, 1984. Pengelolaan Gulma di Perkebunan, PT. Gramedia.,Jakarta.

Tjitrosoepomo. G, 1989. Taksonomi tumbuhan (Spermatophyta). Yogyakarta. Gadjah Mada University Press.

Van Steenis. C.G.G.J. 2002. Flora Untuk Sekolah di Indonesia.: PT. Pradnya Paramitha, Jakarta. 